\title{
The Effectiveness of Using the Portfolio Assessment Model to Improve Student Self-Regulated in Economic Learning
}

\author{
Defika Putri Nastiti; Sigit Santoso; Sudiyanto \\ Sebelas Maret University, Indonesia
}

http://dx.doi.org/10.18415/ijmmu.v9i2.3484

\begin{abstract}
The study aimed to determine: (1) the differences in the self-regulated of students in economics learning using a portfolio assessment model and without using a portfolio assessment model, and (2) the effectiveness of using a portfolio assessment model on students' self-regulated in economics learning. This research is a quasi-experimental study with a randomized control group pretest-posttest design. The population of this research is class XI students majoring in Social Sciences (IIS) for the academic year 2021/2022 which consists of four classes with a sampling technique, namely cluster random sampling. Based on the lottery results, class XI IIS 1 and 2 were given a portfolio assessment model and class XI IIS 3 and 4 did not use the portfolio assessment model. Data collection techniques used are indirect communication techniques. The data collection tool used is a learning self-regulated questionnaire. The hypothesis was tested using parametric statistics, namely the two-tailed t-test with the help of the SPSS version 20 program at a significance level of 0.05 . Based on the results of data analysis, it can be concluded that: (1) there are differences in the self-regulated learning of students in economic learning using a portfolio assessment model and without a portfolio assessment model, and (2) the effectiveness of using a portfolio assessment model on student self-regulated in economics learning is 0.31 .
\end{abstract}

Keywords: Effectiveness; Portfolio Assessment Model; Self-Regulated Learning; Economic Learning

\section{Introduction}

Economics learning is one of the dynamic learning and is often found in the daily life of students. Concepts about the needs of human life, priority scale, financial literacy, prices, supply, demand, profit, resource scarcity are things that are encountered in economic activities and are taught in economics subjects at the formal education level. So in connection with this, economics subjects must be taught according to the needs of students to face the challenges that will be encountered in the future. This is in line with one of the objectives of economic learning as stated in government regulation no. 22 of 2006 concerning content standards, namely forming responsible, wise, and rational by having knowledge and skills of economics that are useful for oneself, 
However, at this time economics learning is learning that is less attractive to students. That's because students think economics learning is a difficult lesson to learn and understand. This causes students to find it difficult to apply economic activities in everyday life and this causes the objectives of economic learning to have not been achieved optimally.

To achieve the goals of economic learning to the fullest, economics learning must also achieve the objectives of evaluating learning outcomes. Namely evaluation of cognitive, affective, and psychomotor outcomes. Because society is currently facing the era of the industrial revolution 4.0, in this era the education sector encourages the development of a more personal way of learning, so that students' self-regulated learning and unique approaches to learning are prioritized, the evaluation of learning outcomes in the affective domain in economic learning is believed to play a more important role. important for students. Self-regulated learning plays an important role for students, because students are required to be able to take responsibility for making decisions to carry out the decisions they make.

Efforts to increase the self-regulated learning of students are by setting specific learning goals that lead to increasing self-regulated learning. Teachers must have the will and skills to change the way they relate to students, starting from paying attention to the initial self-regulated of students, the teaching materials used, learning, scenarios or syntax, and learning assessment. From this, one of the efforts that can be made by teachers is to change teaching methods and encourage self-regulated learning of students with assessment techniques that are following the 2013 curriculum, namely alternative tests and assessments.

One of the efforts that teachers can do to change teaching methods and encourage self-regulated learning of students is by using assessment techniques that are following the 2013 curriculum, namely alternative tests and assessments. The test is a set of questions that must be answered, must be responded to, or tasks that must be carried out by the person being tested. The test consists of a multiple-choice test, a true-false test, a matching test, a completion test, and a short answer test. Authentic alternative assessment is an assessment that can describe the increase in student learning outcomes both in the context of observing, reasoning, trying, and building networks. The authentic assessment also allows students to demonstrate their competence in actual learning,

Authentic assessment consists of project appraisal, performance appraisal, and portfolio assessment. Project assessment is an activity of assessing tasks that must be completed by students according to a certain period/time. Completion of the task in question is in the form of an investigation carried out by students, starting from planning, data collection, organizing, processing, analyzing, and presenting data. Performance appraisal is an assessment that involves the participation of students, especially in the process and aspects to be assessed. The teacher can do this by asking students to name the elements of the project/task that they will use to determine the completion criteria.

One of the problems that arise in learning economics for students at MAN 1 Bandar Lampung is the absence of an assessment model that can increase students' learning self-regulated. Of all the alternative assessments described, portfolio assessment becomes an alternative assessment that can increase learning self-regulated, because according to Blerkom (2018: 160) portfolio assessment can be adjusted to the needs of each student. Most classroom assessment techniques are designed to be administered to all students in the class at the same time and measure shared educational goals and objectives. The assessment tests, which have been used by most schools in Indonesia, have not been able to maximally achieve individual learning goals or increase learning self-regulated. However, a specific portfolio is designed specifically for each student based on the goals and objectives that have been set for these students. Portfolio assessment can measure the level of ability of students as a whole, even in its characteristics, portfolio assessment is an assessment that requires showing the results of collaboration between teachers and students. Portfolio assessment is not just a collection of student work, but a selection process based on criteria and the collection of student work from time to time. 
Applying the portfolio assessment model can help students learn how to evaluate their work. Some students are relatively clueless about how to evaluate their work. They are often unsure of what teachers are looking for in sample work and are surprised by the grades they receive. However, in developing portfolios, students work with the help of their teachers developing the criteria by which to evaluate a sample of work. They are expected to eventually be able to see samples of their work, evaluate each sample, and enter their best sample.

Based on the analysis of various problems above, teachers and students of class XI IIS at MAN 1 Bandar Lampung need a portfolio assessment model to increase the self-regulated of students in economic learning. In previous studies, a portfolio assessment model has been produced. The results of the validation of the portfolio assessment model carried out by validators of media experts and material experts indicate that the portfolio assessment model is appropriate for students to use to increase learning self-regulated. Therefore, further research was carried out to know the effectiveness of the use of the assessment model on the self-regulated of students in economic learning.

The purpose of this study is to determine: (1) the difference in the self-regulated of students in learning economics using a portfolio assessment model and without a portfolio assessment model and (2) the effectiveness of using a portfolio assessment model on the self-regulated of students in economics learning.

\section{Research Methods}

This research was carried out at MAN 1 Bandar Lampung in the 2021/2022 academic year. The subjects of this study were students of class XI MAN 1 Bandar Lampung. The research method used is a quasi-experimental method with two experimental classes and two control classes. The experimental group was given a portfolio assessment model, while the control class was not given a portfolio assessment model. This research is a quasi-experimental study with a randomized control group pretestposttest design.

The population of this study was chosen as the research sample. The students of class XI MAN 1 Bandar Lampung for the academic year 2021/2022 which consisted of twelve classes, this selection was because it was following the needs analysis concerning the assessment model and the availability of facilities and infrastructure that could support the use of the assessment model. portfolio. The research sample was taken from four classes with a cluster random sampling technique. Based on the results of the lottery, class XI IIS 1 and 2 were given a portfolio assessment model and class XI IIS 3 and 4 did not use a portfolio assessment model.

The data collection technique used in this study is an indirect communication technique. Indirect communication techniques are used to measure the level of learning self-regulated of students. The measuring instrument used is a closed questionnaire based on a Likert scale. The self-regulated questionnaire used was adapted from Wahyudi's research (2012) with fairly good reliability of the questionnaire.

\section{Results and Discussion}

The research data were obtained from students of class XI MAN 1 Bandar Lampung, learning self-regulated data was obtained from a self-regulated learning questionnaire, with a Linkert scale model with 5 (five) answer options. The learning self-regulated questionnaire was distributed to 120 students. The data obtained from the questionnaire was then tabulated on the data. The number of self-regulated learning questionnaire instruments is 34 statement items. As for the average results of the student self- 
regulated learning questionnaire using the portfolio assessment model and without using the portfolio assessment model.

Table 1. Distribution of Students' Self-Regulated Learning Questionnaire Results

\begin{tabular}{ccccccc}
\hline Class & $\begin{array}{c}\text { Amount of } \\
\text { data }\end{array}$ & $\begin{array}{c}\text { The highest } \\
\text { score }\end{array}$ & $\begin{array}{c}\text { Lowest } \\
\text { Value }\end{array}$ & Average & $\begin{array}{c}\text { Standard } \\
\text { Deviation }\end{array}$ \\
\hline \multirow{2}{*}{ Pre-test } & Experiment & 60 & 154 & 90 & 118.0 & 16.99 \\
\cline { 2 - 7 } Posttest & Control & 60 & 140 & 90 & 113.0 & 13.02 \\
\cline { 2 - 7 } & Experiment & 60 & 165 & 100 & 135.5 & 16.05 \\
\cline { 2 - 7 } & Control & 60 & 154 & 100 & 122.2 & 15.62 \\
\hline
\end{tabular}

Based on the table above, it can be seen that the average self-regulated learning of students after using the portfolio assessment model is higher than the average self-regulated learning of students without using the portfolio assessment model. The self-regulated learning of students using the portfolio assessment model is $\mathbf{1 3 5 . 5}$ and the average self-regulated learning of students without using the portfolio assessment model is 122.2 .

Table 2. Data Normality Test Results

\begin{tabular}{ccccc}
\hline & Appraisal Model & \multicolumn{3}{c}{ Kolmogorov-Smirnova } \\
\cline { 2 - 5 } & & Statistics & df & Sig. \\
\hline $\begin{array}{c}\text { Self-regulated } \\
\text { Learning }\end{array}$ & Portfolio & 0.190 & 60 & $0.058^{*}$ \\
\cline { 2 - 5 } & Conventional & 0.161 & 60 & $0.165^{*}$ \\
\hline
\end{tabular}

Table 3. Results of Data Homogeneity Test

\begin{tabular}{ccccc}
\hline \multirow{2}{*}{ Dependent List } & \multicolumn{4}{c}{ Levene Test } \\
\cline { 2 - 5 } & Statistics & df1 & df2 & Significance \\
\hline $\begin{array}{c}\text { Self-regulated learning of } \\
\text { students }\end{array}$ & 0.130 & 1 & 39 & 0.720 \\
\hline
\end{tabular}

The prerequisite analysis test shows that research data on self-regulated learning of students is normally distributed and with homogeneous variance. Therefore, the hypothesis test uses parametric statistics of the t-two-tailed test. Hypothesis testing was carried out with the help of the SPSS version 20 program. The null hypothesis $\left(\mathrm{H}_{0}\right)$ was accepted if the calculation significance value (sig.) was greater than the research significance level used, namely $\alpha=5 \%(0.05)$. However, if the calculation significance value (sig.) is smaller than the significance level $\alpha=5 \%(0.05)$ then $\mathrm{H}_{0}$ is rejected. The summary of the data on the results of hypothesis testing is presented in table 4.

Table 4. Summary of Research Hypothesis Test Results

\begin{tabular}{lcc}
\hline & Significance & H0 \\
\hline Self-regulated learning of students & 0.011 & Rejected \\
\hline
\end{tabular}

Based on the summary of the results of the hypothesis test in table 4, it is known that the significance value of the data calculation (Asymp sig.) for Self-regulated learning is 0.011 or less than 0.05 , so the null hypothesis is rejected. In other words, there are differences in the learning self-regulated of students between those using the portfolio assessment model and the self-regulated learning of students without using the portfolio assessment model.

The summary of the results of the calculation of the effectiveness of the use of the portfolio assessment model on learning self-regulated is presented in table 5. 
Table 5. Summary of Gain. Test Results

\begin{tabular}{cccc}
\hline & Class & G & Category \\
\hline The effectiveness of using the portfolio & Experiment & 0.31 & Currently \\
\cline { 2 - 4 } assessment model on Self-regulated learning & Control & 0.06 & Low \\
\hline
\end{tabular}

Based on Table 5, it is known that the effectiveness of using the portfolio assessment model is moderate. This shows that the use of the portfolio assessment model can increase the self-regulated of students in learning economics.

The use of the portfolio assessment model can identify and identify the location of students' weaknesses and strengths which are used as input to improve the learning methods or methods used, while for students it can be used for reflection and self-assessment about the quality and quantity of their work and progress in achieving learning objectives. Blerkom (2018: 161) states that Portfolio assessment provides follow-up material from work that has been done by students so that teachers and students have the opportunity to develop their abilities. In classroom assessment, portfolios can be used to achieve the following objectives: (a) Knowing the progress experienced by students; (b) Documenting the ongoing learning process; (c) Paying attention to the best student performance; (d) Improving the effectiveness of the learning process; (e) Exchanging information with parents/guardians of students and other teachers; and (f) Accelerating the growth of positive self-concept in students (Kusaeri, 2014:127).

Based on the problems faced by teachers and students in learning economics, teachers, and students hope that there is an alternative assessment that can help teachers and students evaluate learning that can increase self-regulated learning. portfolio assessment to increase self-regulated learning. The portfolio assessment model is expected to be able to answer problems and also be able to help both teachers and students evaluate ongoing learning outcomes so that they can be better in the future.

\section{Conclusion}

Self-regulated learning is an active and constructive process of students in setting goals for their learning process and trying to monitor, regulate, and control cognition, motivation, and behavior, which are then all directed and driven by goals and prioritizing the environmental context. Students who have high learning self-regulated are students who are metacognitive, motivational, and behaviorally active participants in the learning process. Self-regulation in learning also brings students to become masters in their learning. The perspective of Self-regulated learning in learning and learning achievement is not only special but also has implications for how teachers should interact with students, and how schools should be organized. From the results of data analysis, it can be concluded that:

\section{Reference}

Adam DM. 1992. Portfolio of Assessment and Social Studies: Collecting, Selecting, and Reflecting on What Is Significant. Social Education 56 (2): 103-105.

Alwisol. 2010. Personality Psychology. Malang: UMM Press

Arifin, Zaenal. 2008. Learning Evaluation: Principles, Techniques, and Procedures. Bandung: Rosda Karya.

Arikunto, S. 2010. Research Procedure a Practical Approach. Jakarta: PT Rineka Cipta. 
Hidayati, Kana and Endang Listyani. 2012. Theory on the meaning and indicators of learning selfregulated, in http://id.shvoong.com/socialsciences/education/2193115-self-regulated-learning.

Kunandar. 2013. Authentic Assessment (Assessment of Student Learning Outcomes. Based on the 2013 Curriculum). Jakarta: Rajawali Press.

Livingston, RB, Reynolds, CR, \& Willson, V. 2004. Measurement and Assessment in Education. New Jersey: Pearson Education, Inc.

Minister of Education and Culture Regulation No. 65 of 2013. Regarding Standards for the 2013 Primary and Secondary Education Process. Jakarta: Ministry of Education and Culture.

Permendikbud No. 66 of 2013. Regarding Assessment in the 2013 Curriculum. Jakarta: Depdikbud.

Minister of Education and Culture Regulation No. 104 of 2014. Regarding Assessment of Learning Outcomes by Educators in Primary and Secondary Education. Jakarta: Ministry of Education and Culture

Ross W.E. 1996. The Role of Portfolio Evaluation in Social Studies Teacher Education: How Evaluation Practices Shape Learning Experiences. Articles: Social Education 60 (93): 162-166.

Zimmerman, BJ. 2000. Attaining Self-Regulation: A Social Cognitive Perspective. New York: University of New York.

Zimmerman, BJ. 2002. Becoming a Self-Regulated Learner: An Overview Theory into Practice. Journal of Educational Psychology. 41 (2), pp. 64-70.

\section{Copyrights}

Copyright for this article is retained by the author(s), with first publication rights granted to the journal.

This is an open-access article distributed under the terms and conditions of the Creative Commons Attribution license (http://creativecommons.org/licenses/by/4.0/). 